\title{
In Pursuit Of Personal Conviction: Upon The Civil War Pocket Diaries Of Emilie Frances Davis, A Freeborn Black Woman [A Short Communication]
}

\author{
Angela K. Brown \\ E-mail: brownlas6@aol.com \\ Doi:10.7575/aiac.alls.v.4n.2p.147 \\ Received: 01/04/2013 \\ URL: http://dx.doi.org/10.7575/aiac.alls.v.4n.2p.147 \\ Accepted: 03/06/2013
}

\begin{abstract}
Emilie Davis was an African-American woman living in Philadelphia during the U.S. Civil War. Emile's diaries are a transcription of Emilie's three pocket diaries for the years 1863, 1864, and 1865. In them, she recounts black Philadelphians' celebration of the Emancipation Proclamation, nervous excitement during the battle of Gettysburg, and their collective mourning of President Lincoln. The diary allows readers to experience the war in real time, as events unfolded for Civil War Americans.
\end{abstract}

Key Words: African American Literature, Black History

Once man understands the social environment which surrounds him, it will determine the ground on which he walks on. We live in a society that is based on how we relate to others. It is from how we judge others we perceive our own identities. It is from how we judge others, a level of structure is made. From an organizational climate, permiates a class structure. A class structure may develop into a community. It is from this community that determines experience.

Emile Francis Davis kept a diary of perceived convictions from 1863 - 1865 that told of her experience as a biracial female during the time of the Civil War. Davis diary revealed the political, economical and social constraints which occurred in a free slave community in Philidelphia. Davis kept in her journal personal conflicts which affected her from personal experience. The emancipation would change history in how America would be viewed throughout the world.

It is important for Emile to describe the connection between social constraints of society during that time period. The success of enterprise would create an mass emigration of free blacks that would someday abolish slavery. Emile came from a properous community of biracial blacks who were successful. Emile was born a free slave. Her decedents would be free slaves. Enterprise would motivate black freedom from slavery.

Family was very important to black people at this time. It was common for a free black to buy their wife and children as slaves to free them and make them apart of the family. During slavery it was common for slave owners to separate families so they would not educate themselves and cause a slave revolt. Emile expresses how it is important to keep family together. Emile describes how she values her relationship with family and friends.

Emile describes how she assimilates the difference between race, class and gender. There are variable differences in how we relate to race, class and gender. Often between each structure there are variable disputes which separates each structure: with the division of classes there is upper class and lower class, with the division of race there are whites, blacks and malatoes, with the division of gender there are male and female. Each division is responsible of their own convictions.

Emile lived in a free community of working class family. Emile being raised in the church, became her foundation to emerge stability of her life. Emile religious faith and education would someday determine her own identity in society.

Emile's diary stories will be noted for her personal conviction which will be measured by substinence in celebration of renewed freedom. Emile's diary survived to illuminate time. Emile's diary is an accountable document relative of black female experience. Emile's unique personal recorded evictions reveal the history of America that will not be forgotten. 